\author{
Małgorzata Klaudia Kozłowska \\ Magister, adwokat \\ Doktorantka w Zakładzie Prawa Administracyjnego Wydziału Prawa, \\ Administracji i Ekonomii Uniwersytetu Wrocławskiego \\ m.kozlowska86@wp.pl
}

DOI: 10.35117/A_ENG_18_03_04

\title{
Plan for sustainable development of collective public transport as a tool to shape the passenger transport market in Poland
}

\begin{abstract}
A collective public transport becomes increasingly important as a factor in balancing the functioning of the various means of transport. The public transport can be carried out on Polish territory and in border areas, in road and rail transport, maritime transport and inland waterway. A plan for sustainable development of collective public transport is an instrument which determine a way how to perform a public transport in a certain area. A transport plan is an act of local law. It determines the rules of organization, operation and financing of regular passenger transport in the public transport by which is regarded as a tool to shape the passenger transport market in Poland
\end{abstract}

Keywords: Plan for sustainable development of collective public transport; Transport plan; Collective public transport

\section{Introduction}

Transport is the foundation of the economy and society, because mobility is extremely important for the functioning of the internal market and for the quality of life of citizens who are free to travel. Mobility is a part of everyday human activity related to the choice of the purpose, time and route of travel, and even more broadly with the making of "life choices" associated with traveling (place of work, residence, the fact of starting a family). Mobility, which is significantly influenced by the way transportation is organized, is the behavior subject to conscious shaping - both by the participant (the person performing the journey) and by "external elements" - transport managers (including infrastructure), managers of the area and other participants ( users) of the transport system. [7]

Effective collective public transport is a prerequisite for maintaining the well-being of a region. It is the key to reducing congestion, reducing emissions, creating new jobs and accelerating economic growth. [17]

For 7 years in Poland, self-government authorities have been developing basic principles and plans for the functioning of collective public transport in a given area. Such activities can be called the transport policy of the region: a city, a commune, a district, voivodships, which is an important area of the state's economic policy.

The tool helping to design efficiently operating public transport in the region, corresponding to the expectations of the local community, and also taking into account the need to integrate the means of locomotion, their modernization and expansion is a plan for the sustainable development of public transport. The plan, to be perceived as an effective instrument for shaping the passenger transport market in Poland, must take into account all necessary elements imposed by the act in relation to local needs. As M. Kruszyna remarks, the quality of these documents depends on the fate of public communication [8], and hence the microeconomic policy of the region, the development of urbanized areas, and the widely understood economic policy of the state. 
The article presents what collective public transport is and why its sustainable development should be sought, as well as the tool by which the transport policy of the region is shaped.

\section{The importance of collective public transport}

Collective public transport is becoming increasingly important as a factor in balancing the functioning of various modes of transport, and it also constitutes a significant economic, social and ecological issue. "In the functioning of cities and regions, it fulfills both a social role (it gives people who do not have access to other forms of transport), as well as the role of shaping transport behavior towards limiting car traffic in places where congestion creates a functional and ecological problem" [4].

In Poland, collective public transport and its development should also be perceived as a solution that could counteract the increasing congestion of roads. It should be noted that increased traffic on the roads and streets of city centers causes congestion with undesirable effects such as: longer travel time, air pollution, increase in road accidents, climate change. From the research conducted by TomTom in 2016 - known from car navigation systems - it follows that out of 390 cities from six continents, as many as 12 Polish cities: Łódź, Lublin, Kraków, Warsaw, Wrocław, Poznań, Bydgoszcz, Tricity, Szczecin, Białystok, Bielsko - Biała and Katowice have been qualified to one of the most congested agglomerations in the world (Fig.1).

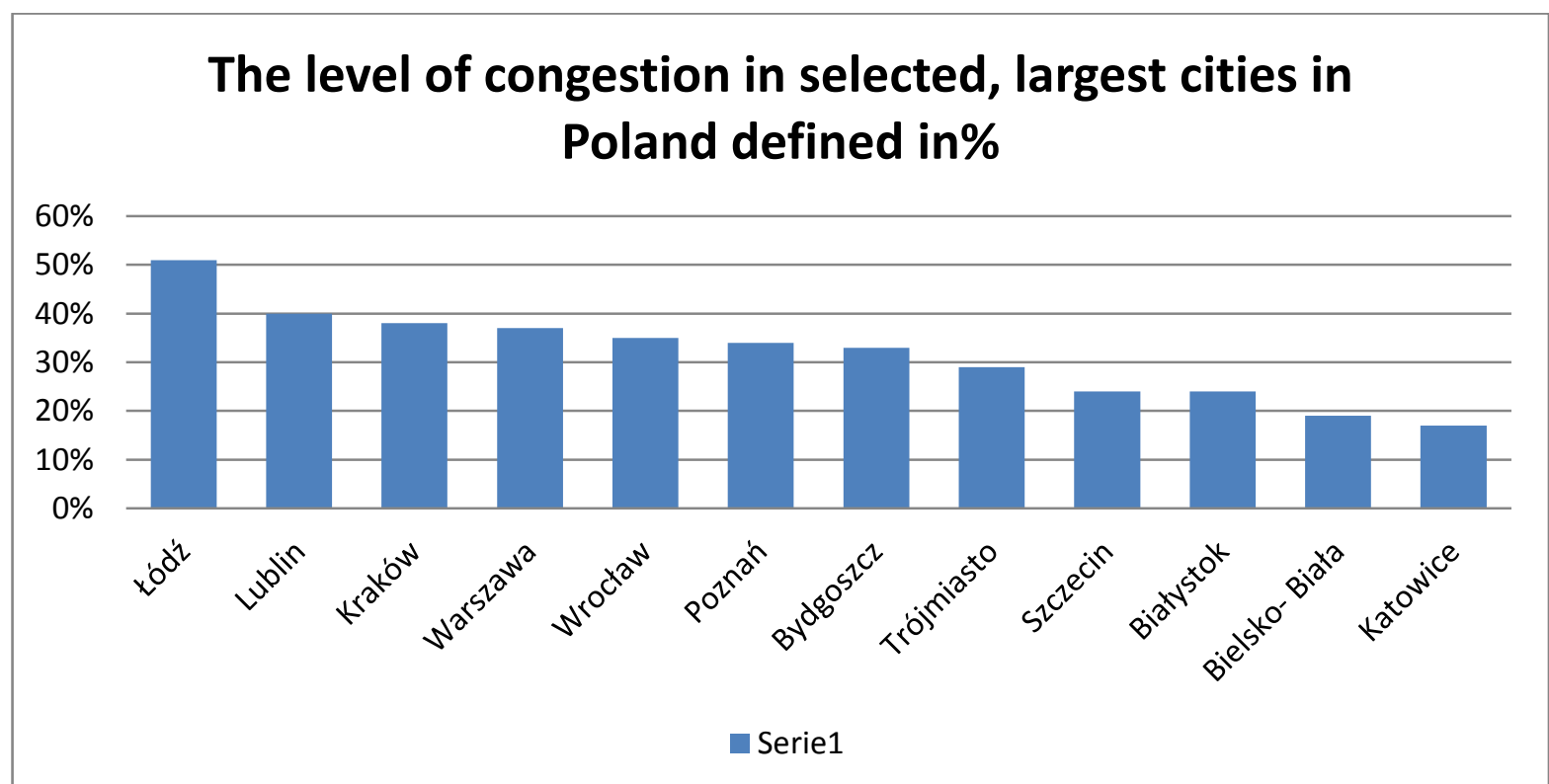

1. The level of congestion of selected, largest Polish cities assessed by TomTom "in terms of difference in time of car travel in the so-called Free Flow conditions and real, taking into account current driving conditions on local roads, exits and motorways " [9]. Source: TomTom Traffic Index 2016 [14]

In the light of the data presented above, it is postulated that "all possibilities should be used to counteract the increasing congestion of roads, which arises, among others, as a result of the cancellation of passengers from public transport for passenger car trips. One of such possibilities is efficient and effective public transport, providing access for every traveler to public transport, which is an alternative to individual motorization. " [4]. Public transport, so that it can effectively attract travelers who choose non-public transport and private transport should be competitive with them. The basic measures to assess the competitiveness of public transport are travel time, cost of travel and the quality of transport service. Moreover, it should take into account the expectations of a given local community (commune, district, 
voivodship) regarding guaranteeing access to public mass transport services, ensuring diversification in the selection of the means of locomotion as well as putting into service of functional vehicles technically and equipped with devices facilitating travel.

What's more, sustainable development of public transport and its integration, by harmonizing the tariff and ticket systems and the creation of a network of well-functioning interchanges, is not only a remedy for urban congestion, but also reduces the negative impact of transport on the environment, including emissions of carbon dioxide and noise.

\section{The concept of collective public transport}

According to the definition included in the Act on Public Collective Transport [15] (hereinafter referred to as the Act) collective public transport should be understood as a regular public transport of people carried out at specified intervals and on a specified communication line, communication lines or communication network (Article 4 paragraph 1 point 14 of the Act).

It is clear from the statutory definition that for a given transport to qualify as being within public transport three conditions must be fulfilled, namely it must be:

1) widely available, which means that each person should be able to use a given means of communication, provided that the conditions included in the rules of carriage are met,

2) regularly carried out, and therefore transport should take place at predetermined and fixed intervals given in the public timetable,

3 ) implemented on a specific line or communication network, and thus the carrier must be guaranteed access to communication stops, i.e. places for passengers to get on or off on a given communication line, in which information about, in particular, departure times of means of transport marked with according to the rules.

Thus, collective public transport will not be able to name such transports as transport of employees organized by enterprises, tourist transports or transports performed by taxis, or transport by private passenger cars.

Collective public transport may be carried out on the territory of the Republic of Poland and in the cross-border area, in the road, rail, cable, rope-land, sea and inland waterway transport (Article 1 paragraph 1 of the Act). Its organizer, and therefore the entity that ensures the functioning of collective public transport in a given area, is the competent local government unit or the minister competent for transport (Article 4 paragraph 1 point 9 of the Act). In turn, the contractor of the public transport service can be both a public and private entity, ie a self-governmental budgetary establishment and an entrepreneur authorized to run a business in the field of passenger transport, who concluded a contract for the provision of public transport services with the public transport organizer collective agreement on the communication line specified in the contract (Article 4 paragraph 1 point 9 of the Act).

\section{Transport plan}

An instrument with which the way of performing public public transport and the passenger transport market is shaped and managed in a given area, and thus creates the attractiveness of public transport, is a plan for the sustainable development of public mass transport (hereinafter referred to as a transport plan).

The transport plan is an act of local law (Article 9 (3) of the Act) of a strategic and implementation nature, adopted by the body constituting a local government unit, defining the principles of organization, functioning and financing of regular passenger transport in public transport. This act regulates the sphere of rights and obligations of citizens as well as administrative and economic entities involved in the implementation of public transport services covered by the plan. It provides a legal and substantive framework for managing the functioning and development of collective transport within the territorial self-government 
unit. The legal basis for issuing a transport plan is the act - art. 9 and the Regulation on the detailed scope of the plan for sustainable development of public mass transport (hereinafter referred to as the Regulation) [11]. According to the aforementioned article of the Act, the preparation of a transport plan by the organizer of public transport may be obligatory or optional. "The obligation to develop a transport plan has all marshal offices if they plan to organize public transport services in voivodship passenger transport. In the case of other local government units (commune, district) or their associations (inter-municipal association, district union, county-communal association, metropolitan union), the obligation to develop a transport plan applies when these units:

a) they plan to organize transport of public utility character in municipal or district passenger transport,

b) are inhabited by an appropriate number of inhabitants (at least 50,000 municipality, at least 80,000 communes agreement, at least 80,000 inter-municipal association, at least 80,000 at least district, at least 120,000 district agreements, district union with at least 120 thousand inhabitants) " [4].

The transport plan may be developed by a given public transport organizer optionally in an area with fewer inhabitants. This document is of medium-term nature and is valid, depending on the assumptions adopted by the operator, from 10 to 12 years. The costs of preparing a transport plan shall be borne by the operator of the collective public transport. The transport plan should cover all collective public transport services, and therefore services of general interest and commercial services, while in the decision-making part it concerns only services ordered by local self-government as services of a public utility character. At the same time, it should be noted that the transport plan does not regulate commercial services as regards the establishment of routes and rules for their servicing because it belongs to the domain of free market activity, but it should take into account the effect of commercial and public utility services on public transport..

\section{Transport plan as an instrument for shaping the passenger transport market in Poland}

Pursuant to the provisions of the Act, the organizer of collective public transport has the obligation to plan, organize and manage transport. The introduction of a transport plan in a given local government unit and its implementation and updating is part of the scope of tasks consisting of organizing transport. The reasons for which the legislator imposed on local selfgovernment units the obligation to draw up a transport plan are at least several, and this is:

1) growing share of individual transport in transport in the most urbanized and populated areas,

2) the need to increase the efficiency and competitiveness of public mass transport and to promote economic modes of transport and transport services,

3) the need to use street space for the residents' utility by creating parking lots and pedestrian or bicycle zones,

4) konieczność ukształtowania spójnego, sprawnego, rozbudowanego i zdywersyfikowanego rynku przewozów pasażerskich,

5) promoting collective public transport,

6) improving travel safety,

7) integration of the motorway and street system, while reducing the costs of construction and maintenance of transport infrastructure [1].

In order to be able to achieve the above-mentioned goals and satisfy these needs, it is necessary to coordinate and synchronize many elements from different areas at different levels, this is what the transport plan is for, used as a tool to plan and manage public transport. The transport plan consists of text and graphics. He should specify in particular (Article 12 paragraph 1 of the Act): 
1) communication network on which it is planned to carry out transport operations of public utility;

2) assessment and forecast of transport needs;

3) anticipated financing of transport services;

4) preferences regarding the choice of the type of transport;

5) rules of transport market organization;

6) desirable standard of transport services in transport of public utility character;

7) predicted method of organizing the passenger information system.

"The catalog of components of the transport plan is not closed. Therefore, each organizer can add other elements that may be necessary for its area, such as the boundaries of city zones available only for ecological public transport vehicles (e.g. fed with biofuels) due to the need to protect the environment or monuments. But it can also describe in detail the communication lines on which commercial transport will be carried out. The text should contain justification for each solution adopted " [6].

The definition of a communication network consists in indicating collective transport means by means of which public transport will take place in a given area (Figure 2). In this part of the transport plan, the organizer may also determine which of the transport services he gives priority in development, determine interchange and integration nodes, identify the key corridors of public transport and indicate the most important transport hubs, link public transport with car traffic, designate the area in which limited there will be individual or nonpublic transport as well as the scope and stages of development of the public mass public transport network

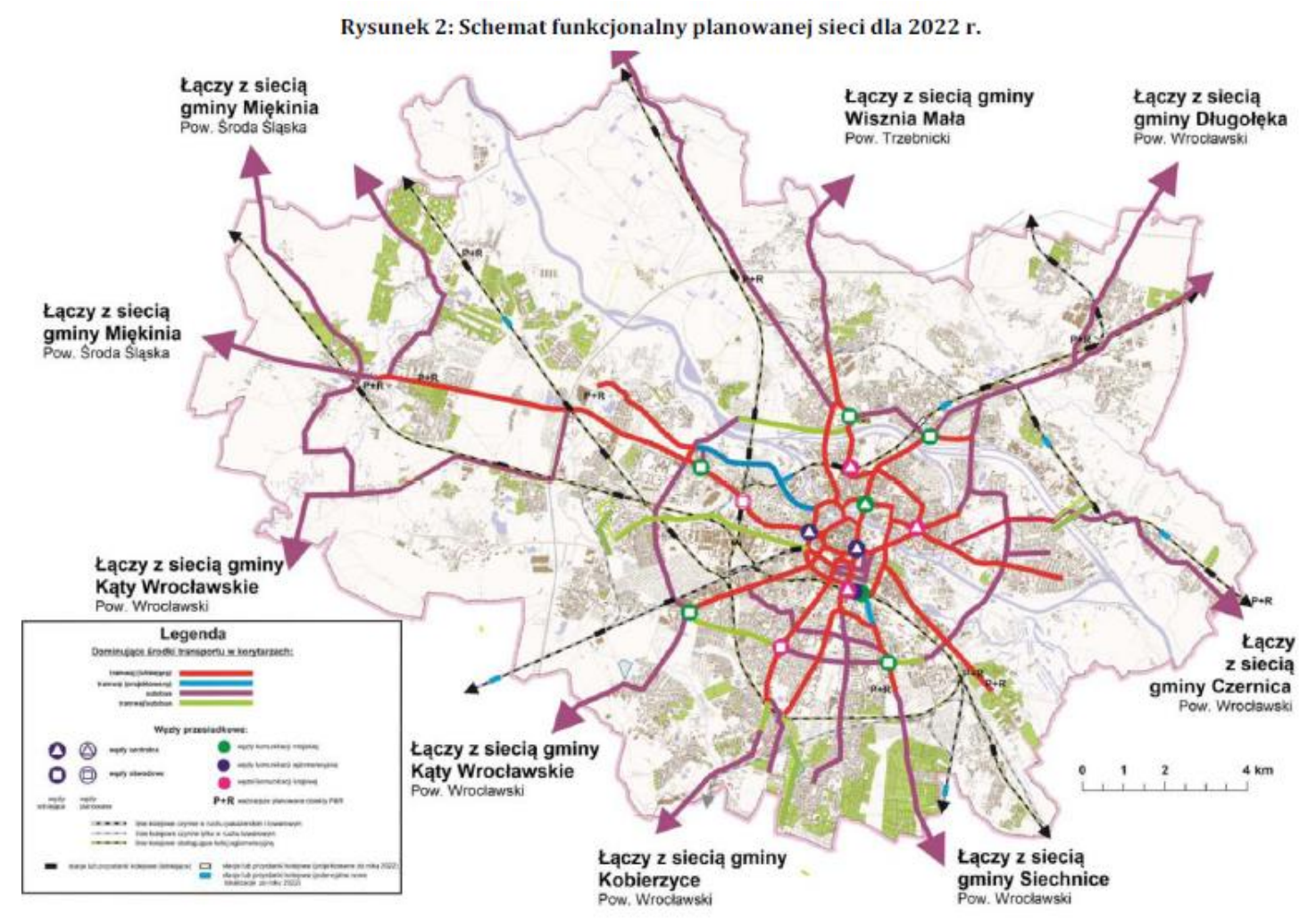

2. An exemplary functional diagram of the planned collective public transport network for 2022 for Wrocław, including public transport, with the help of which public transport will take place in a given area. Among the dominant means of transport in the corridors, the red

color is marked by existing trams, blue - designed trams, purple - buses, and green trams/buses. Source: Sustainable development plan for public transport in Wrocław - project [10]. 
The second of the essential elements of the transport plan, in the text part containing the assessment and forecast of transport needs, in accordance with $\S 4$ para. 1 point 2 of the Regulation, it should take into account the location of public utilities, the population density of the area covered by the transport plan and providing access for disabled people and persons with reduced mobility to public public transport. Thus, the organizer of public mass transport should take into account not only a balanced investment policy regarding the expansion and modernization of rolling stock, the launching of new transport and connection lines, but also demographic and economic changes taking place in the area. The assessment of demographic trends includes the main factors of the movement potential associated with social groups with similar communication behavior, so that public transport is adapted to the needs of people with diverse age structure and disabled people.

The organizer in the transport plan should include data on the expected financing of transport services, in particular information on the sources and forms of financing public transport ( $\S 4$ item 1 point 3 of the Regulation). For public transport to be an alternative to individual and non-public transport, it should be financially attractive for travelers. The funds allocated to financing public transport should not come exclusively from the amounts obtained from the sale of tickets, nor from price increases for them. Increasing transport performance of public transport vehicles, development of new communication lines and purchase of rolling stock should also be financed from subsidies of the local government unit to inflows from tickets [10].

The transport plan is also to constitute a legal tool that, apart from shaping the passenger transport market in Poland, would increase the efficiency of collective public transport and introduce solutions that would increase the attractiveness of this transport and its competitiveness in relation to individual and non-public transport. Achieving the above objectives is done by specifying in the transport plan the desired standard of transport services in public transport, the anticipated way of organizing the passenger information system and preferences regarding the choice of the type of transport means.

The choice of public transport, as an alternative to passenger cars, is influenced by many factors, such as: a journey without transfer, low cost of travel, ease of ticket purchase, punctuality, speed and travel time, availability of a seat and special accessibility requirements disabled, adjusting the timetable to the needs of passengers, stability of timetables, availability of information, good accessibility to stops, protection against inconvenient waiting conditions for the vehicle, service culture and environmental friendliness [10]. At the same time, in the legislator's opinion, the main factors affecting the attractiveness of public transport are travel time, competitive travel costs and travel comfort. "Travel time can be regulated, among others through appropriate organization of the traffic that prefers vehicles performing transport of a public utility character, as well as through the integration of various transport systems. Competitive travel costs can be achieved by applying appropriate prices and tariffs for transport services, and operating costs co-financed with public funds. The travel comfort that meets the needs and expectations of travelers can be ensured by modern vehicles, easy access to transport infrastructure and friendly information systems. " [16].

In addition to the descriptive part, the transport plan should include a graphic part - a drawing shows the communication network within the boundaries of the area where public transport is to be carried out ( $\S 5$ (1) of the Regulation). The drawing should in particular specify the scale of the figure in numerical and linear form, the administrative boundaries of the local government unit covered by the transport plan, the explanations of symbols and symbols used in the drawing and the designation of integrated transfer nodes located in the area covered by the transport plan ( $§ 5$ section 2 of the Regulation). 


\section{Summary}

The obligation to pass a transport plan by local government units was introduced for the first time in Polish law by the way of an act that came into force from 01.03.2011. Before the Act entered into force, some municipalities prepared documents fulfilling approximate functions to the transport plan, which were developed freely. These documents did not have the status of local law, although in terms of the scope and methodology of the study showed great similarities to the transport plan.

In the world and on the territory of the European Union "for many years the organs of government and self-government authorities of individual countries and their unions have been developing the basic principles of transport operation and legal documents (acts, directives, ordinances) implementing these principles in the economy and social life" [1]. The development of a transport plan, as a transport policy document in a given territory, is supposed to lead to the replacement of road transport with more environmentally friendly types and forms of transport and to shape the passenger transport market in a given area. The sustainable transport system achieved with the transport plan is a mechanism that drives the economy, affects environmental protection and reduces congestion in cities.

At present, no transport plan at the provincial level meets all the statutory requirements listed in art. 12 of the Act and Regulation (Figure 3). The authorities of all selfgovernment voivodships have easily coped with the indication of communication lines on which public transport is planned - railway and with the specification of the standard of transport and quality of transport services. The definition of communication lines on which public transport services are planned is satisfactory should be considered satisfactory in transport plans, assessment of transport needs, presentation of population density of the area covered by the plan, determination of financing sources for transport services or rules of organization of transport. However, most transport plans did not meet the requirements for establishing the coordination of connections between different types of transport, standards including access to public transport for disabled persons and persons with reduced mobility, as well as the forecast of transport needs was not determined. The lack of compliance of individual transport plans with the legal requirements probably stems from the casuistry of this local act. It is indicated that the transport plan should be limited to more general things, such as diagnosing the current state of public transport, defining problems, indicating the directions and ways of solving the problems observed in transport and possible guidelines [3].

Despite the shortcomings occurring in the transport plans, the activities of local governments should be assessed positively, because they give the option of choosing passengers the nature of travel and means of transport, provide comfort and the opportunity to travel for the elderly and disabled and implement a policy of caring for the environment. Nowadays, the offer of public transport is addressed both to those who do not have access to other means of transport - improving their quality of life - as well as to people using individual transport - in order to reduce the negative, functional and ecological effects of mass motorization [13]

Due to the fact that transport plans are currently the only effective tool for the implementation of the policy of sustainable public transport and shaping the passenger transport market in Poland, it is postulated that they are often updated, and supporting research carried out at regular intervals, and their creation promoted among entities that are not legally obliged to do so [2].

Regulation No. 51 of the Minister of Infrastructure and Construction of November 3, 2016.a team was set up to draft a bill amending the act on public transport. The only major change is to apply to transport plans. It is postulated to introduce the obligation to develop a transport plan by all public transport organizers (currently, the obligation to develop a transport plan was imposed only on entities listed exhaustively in Article 9 of the Act). In 
addition, it is planned to modify the scope of the transport plan, where information on passenger flows is to be found on each communication line during the day and on individual days of the week, while passenger lines are to be included in packages including profitable and unprofitable lines. [5] Approving the proposed changes regarding transport plans should be approved. It is believed that transport plans are particularly effective in small municipalities. This is because the communication network, the layout of stops and the volume of passenger traffic can be described in great detail [3]. The proposed changes will impose on all organizers of public mass transport, and therefore not only on municipalities over 50,000 inhabitants, the obligation to pass a transport plan. Moreover, the inclusion of information on passenger flows in the plan will allow the design of new courses and will enable the rationalization of departure times of public transport, thus contributing to the increase of the communication offer for travelers and the more effective operation of the transport plan in a given region. 


\begin{tabular}{|c|c|c|c|c|c|c|c|c|c|c|c|c|c|c|c|c|}
\hline & 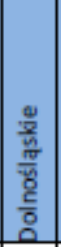 & 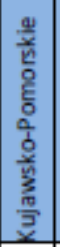 & \begin{tabular}{|l|} 
\\
\\
\end{tabular} & 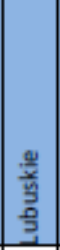 & $\frac{9}{\frac{5}{2}}$ & 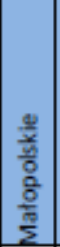 & 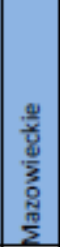 & $\frac{\frac{y}{2}}{\frac{2}{2}}$ & 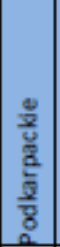 & $\begin{array}{l}\frac{9}{2} \\
\frac{\pi}{3} \\
\\
\end{array}$ & 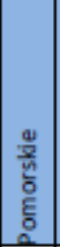 & $\frac{\frac{9}{2}}{\frac{3}{4}}$ & 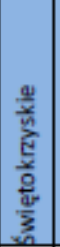 & 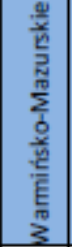 & $\begin{array}{l}\frac{9}{3} \\
\frac{5}{8} \\
\frac{8}{0} \\
\frac{2}{3} \\
3\end{array}$ & 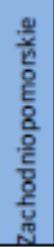 \\
\hline $\begin{array}{l}\text { Wskazanie linii komunikacyjnych na których } \\
\text { planowane jest wykonywanie przewozów } \\
\text { użyteczności publicznej - kolejowych }\end{array}$ & + & + & + & + & + & + & + & + & + & + & + & + & + & + & + & + \\
\hline $\begin{array}{l}\text { Wskazanie linii komunikacyjnych na których } \\
\text { planowane jest wykonywanie przewozów } \\
\text { użyteczności publicznej - autobusowych }\end{array}$ & + & + & + & + & $+/-$ & $+/-$ & $+/-$ & + & + & + & + & - & + & + & + & + \\
\hline Ocena potrzeb przewozowych & + & + & $+/-$ & + & - & + & $+/-$ & + & $+/-$ & + & + & - & $+/-$ & + & $+/-$ & + \\
\hline Prognoza potrzeb przewozowych & - & + & $+/-$ & - & - & + & $+1-$ & + & + & + & + & $+/-$ & - & $+/-$ & $+/-$ & + \\
\hline $\begin{array}{l}\text { Wskazanie lokalizacji obiektów użyteczności } \\
\text { publicznej }\end{array}$ & - & + & + & + & - & + & $+/-$ & + & $+/-$ & + & - & + & + & + & $+/-$ & + \\
\hline $\begin{array}{l}\text { Przedstawienie gęstości zaludnienia obszaru } \\
\text { objętego planem }\end{array}$ & + & + & + & + & + & + & + & + & + & + & - & + & + & + & - & + \\
\hline $\begin{array}{l}\text { Uwzględnienie w ocenie dostępności dla osób } \\
\text { niepełnosprawnych i o ograniczonej zdolności } \\
\text { ruchowej }\end{array}$ & + & $+/-$ & $+/-$ & - & - & + & + & + & $+1-$ & + & - & + & + & + & - & + \\
\hline $\begin{array}{l}\text { Okreslenie zródeł finansowania usług } \\
\text { przewozowych }\end{array}$ & - & + & + & + & $+1-$ & $+1-$ & + & + & + & + & + & + & + & + & $+/-$ & + \\
\hline $\begin{array}{l}\text { Określenie formy finansowania usług } \\
\text { przewozowych }\end{array}$ & - & $+/-$ & + & + & + & $+/-$ & + & + & + & + & $+/-$ & $+/-$ & $+/-$ & $+/-$ & + & + \\
\hline $\begin{array}{l}\text { Preferencje wyboru rodzajów środków } \\
\text { transportowych }\end{array}$ & + & $+/-$ & + & + & + & + & $+1-$ & + & $+/-$ & + & + & + & + & + & + & + \\
\hline $\begin{array}{l}\text { Propozycje wyboru środków transportowych } \\
\text { uwzględniając istniejącą infrastrukturę } \\
\text { transportową }\end{array}$ & + & + & $+1-$ & + & $+1-$ & + & + & + & + & $+/-$ & + & + & + & $+/-$ & + & + \\
\hline Zasady organizacji przewozów & + & + & + & + & + & + & + & + & + & + & + & \begin{tabular}{|l|}
$+/-$ \\
\end{tabular} & + & - & + & + \\
\hline Przewidywany tryb wyboru operatora & - & $+/-$ & + & + & + & $+/-$ & + & $+/-$ & + & + & $+/-$ & $+/-$ & $+/-$ & $+/-$ & + & + \\
\hline $\begin{array}{l}\text { Określenie standardu przewozów i jakości } \\
\text { ustug przewozowych }\end{array}$ & + & + & + & + & + & + & + & + & + & + & + & + & + & + & + & + \\
\hline $\begin{array}{l}\text { Standardy uwzględniają potrzebę zapewnienia } \\
\text { ochrony środowiska naturalnego }\end{array}$ & + & + & $+/-$ & - & + & - & + & + & + & + & + & + & + & $\mathrm{P}+1-$ & + & $+/-$ \\
\hline $\begin{array}{l}\text { Standardy uwzględniają dostęp do ptz dla } \\
\text { osób niepełnosprawnych i o ograniczonej } \\
\text { zdolności ruchowej }\end{array}$ & $+1-$ & $+1-$ & $+1-$ & $+/-$ & $+1-$ & + & + & $+/-$ & $+1-$ & $+/-$ & + & $\mathrm{P}+1-$ & + & $\mathrm{P}+1-$ & $\mathrm{P}+1-$ & $+1-$ \\
\hline $\begin{array}{l}\text { Przewidywany sposób organizowania systemu } \\
\text { informacji dla pasazera zapewnia dostęp do } \\
\text { informacji w zakresie: }\end{array}$ & & & & & & & & & & & & & & & & \\
\hline $\begin{array}{l}\text { - godzin przyjazdu lub odjazdu środków } \\
\text { transportu, }\end{array}$ & + & + & + & + & + & + & + & + & $+/-$ & + & + & + & $+/-$ & + & - & + \\
\hline - obowiązujących opłat za przejazd, & + & + & + & + & + & + & + & + & + & + & + & + & + & + & + & + \\
\hline $\begin{array}{l}\text { - obowiązujących uprawnień do ulgowych } \\
\text { przejazdów środkami publicznego transportu } \\
\text { zbiorowego, }\end{array}$ & - & + & + & - & + & + & + & + & + & + & + & + & + & + & + & - \\
\hline - wezłów przesiadkowych, & + & + & + & + & + & + & + & + & - & $+/-$ & + & + & + & + & + & + \\
\hline $\begin{array}{l}\text { - koordynacji połączeń różnych rodzajów } \\
\text { środków transportu, }\end{array}$ & + & $+1-$ & - & - & + & $+1-$ & + & - & - & - & $+1-$ & $+1-$ & $+/-$ & $+/-$ & + & - \\
\hline - regulaminów przewozu osób; & - & + & + & + & + & + & + & + & + & + & + & + & + & + & + & + \\
\hline Kierunki rozwoju ptz & + & - & + & + & + & + & + & + & + & + & + & + & + & - & - & + \\
\hline
\end{tabular}

3. Compliance of particular voivodship transport plans with legal requirements, where + means meeting the requirements, - means not meeting the requirements, and $+/$ - means formal fulfillment of requirements, but essentially to a very small extent.

Source: Transport plans of voivodships in Poland, compliance with legal requirements, good and bad habits [12] .

\section{Source materials}

[1] Bieńczak M., Jakubek A., Kiciński M., Kwaśnikowski J., Plany transportowe w Polsce i innych krajach - zawartość i realizacja, Logistyka 3/2014, s. 515 - 516. 
[2] Bieńczak M., Jakubek A., Kiciński M., Kwaśnikowski J., Plany transportowe w Polsce i innych krajach - zawartość i realizacja, Logistyka 3/2014, s. 520.

[3] Chmurki M., Kondycja Publicznego Transportu Zbiorowego, Senacki Zespół Infrastruktury, Kancelaria Senatu, Warszawa 2013, s. 18.

[4] Informacja Ministra Infrastruktury i Rozwoju na temat przygotowań do wdrożenia ustawy z dnia 16 grudnia 2010 r. o publicznym transporcie zbiorowym na posiedzeniu Komisji Infrastruktury oraz Komisji Samorządu Terytorialnego i Polityki Regionalnej Sejmu Rzeczypospolitej Polskiej w dniu 3 grudnia 2014 r., Warszawa 2014, s. 2.

[5] Karolak A., Informacja $\mathrm{z}$ posiedzenia zespołu ds. opracowania projektu ustawy o zmianie ustawy o publicznym transporcie zbiorowym $\mathrm{z}$ dnia 28.02.2017 r., http://igkm.pl/ftp/dok/201703/1.pdf, dostęp 17.08.2017 r.

[6] Kowalski B., Czy plany transportowe są potrzebne?, Railway Business Forum, http://www.rbf.net.pl/wiecej,Czy-plany-transportowe-sa-potrzebne,736, 14.03.2017 r.

[7] Kruszyna M., Dworzec kolejowy jako węzeł mobilności, Przegląd Komunikacyjny 10/2012, s. 34.

[8] Kruszyna M., Niektóre aspekty nowej ustawy o publicznym transporcie zbiorowym, Przegląd Komunikacyjny 1 - 2/2011, s.60.

[9] Lódź najbardziej zakorkowanym miastem w Europie, http://www.bankier.pl/wiadomosc/Lodz-najbardziej-zakorkowanym-miastem-wEuropie-7244619.html, 10.03.2017 r.

[10] Plan zrównoważonego rozwoju transportu zbiorowego Wrocławia- projekt, listopad 2016, http://bip.um.wroc.pl/artykul/127/21057/konsultacje-w-sprawie-planuzrownowazonego-rozwoju-publicznego-transportu-zbiorowego-wroclawia-plantransportowy, 14.03.2017 r.

[11] Rozporządzenie Ministra Infrastruktury z dnia 25 maja 2011 r. w sprawie szczegółowego zakresu planu zrównoważonego rozwoju publicznego transportu zbiorowego (Dz.U.2011.117.684 z dnia 2011.06.08).

[12] Rytel K., Plany transportowe województw w Polsce, zgodność z wymogami prawa, dobre i złe nawyki, Raport nr 2/2015,Warszawa 2015.

[13] Świątecki P., Publiczny transport zbiorowy, Przegląd Komunikacyjny 5-6/2011, s. 75.

[14] TomTom Traffic Index 2016, https://www.tomtom.com/en_gb/trafficindex/list?citySize=ALL\&continent=ALL\&co untry=PL, 11.03.2017 r.

[15] Ustawa $\mathrm{z}$ dnia 16 grudnia 2010 r. o publicznym transporcie zbiorowym (Dz.U.2016.1867 t.j. z dnia 2016.11.18).

[16] Uzasadnienie projektu ustawy o publicznym transporcie zbiorowym, s. 2- 3, http:// orka.sejm.gov.pl/Druki6ka.nsf/0/.../\$file/2916-uzasadnienie.doc, 09.03.2017 r.

[17] White Paper - Roadmap to a Single European Transport Area - Towards a competitive and resource efficient transport system, $\operatorname{COM}(2011) 144$ final, Brussels 2011 . 